\title{
HABITAT AND GROWTH CONDITIONS \\ OF THE RARE POTAMOGETON HYBRIDS: \\ $P . \times$ SPARGANIFOLIUS LEAST. EX FR. AND P. $\times$ NERICIUS HAGSTR. IN THE DRAWIEŃSKI NATIONAL PARK
}

\author{
MAREK KRASKA ${ }^{1}$, RYSZARD PiOTROWICZ ${ }^{1}$, JOLANTA KUJAWA-PAWLACZYK ${ }^{2}$ \\ ${ }^{1}$ Department of Water Protection, Biological Faculty, \\ Adam Mickiewicz University \\ Drzymały 24, 60-613 Poznań, Poland \\ e-mail: marek kraska@poczta.onet.pl \\ 2 Department of Forest Botany, Agricultural University \\ Wojska Polskiego 71D, 60-625 Poznań, Poland
}

(Received: April 7, 2003. Accepted: December 3, 2003)

\begin{abstract}
The two pondweed taxa, new for the Polish flora, were found in the Drawa River in the Drawieński National Park (north-western Poland). Patches of $P . \times$ sparganiifolius started about $400 \mathrm{~m}$ below the mouth of the left-bank tributary, the Korytnica River, and ended about $5.5 \mathrm{~km}$ further downstream. The population colonized mainly a sandy substrate with varied particle size, moderately deep water, and moderate water flow rate. The patches were very dense and composed nearly exclusively of $P . \times$ sparganiifolius. They occurred mainly in the main current of the Drawa, and were up to several dozen metres long. By contrast, $P . \times$ nericius was found only in a small creek with stagnant water, at the edge of a patch dominated by $P . \times$ sparganiifolius, on a substrate composed of mud and sand, at the depth of $40-60 \mathrm{~cm}$.
\end{abstract}

KEY WORDS: pondweeds, Potamogeton $\times$ sparganiifolius, Potamogeton $\times$ nericius, growth conditions, distribution, aquatic plants, Poland.

\section{INTRODUCTION}

The presence of Potamogeton $\times$ sparganifolius and $P . \times$ nericius in the Drawa River was noticed during research on aquatic ecosystems of the Drawieński National Park in 1998. Observations were repeated in 1999. It is the first and so far the only locality of these taxa in Poland (Zalewska-Gałosz 2002).

Within this genus, hybrids are relatively common (Fant et al. 2001a, b). The known centres of Potamogeton hybridisation are: Great Britain, Denmark, Sweden and Japan (Wiegleb 1988).

$P . \times$ sparganifolius is thought to have resulted from crossing $P$. gramineus and $P$. natans, while $P . \times$ nericius is derived from crossing $P$. alpinus and $P$. gramineus (Zalewska-Gałosz 2002). The population of $P . \times$ sparganifolius covers about $2 / 5$ of the length of the river within the borders of the Park, while $P . \times$ nericius is very rare and represented by a small number of individuals (Fig. 1).

The Drawa is one of the major rivers of Pomerania in the catchment area of the Noteć River. The source of the river is located in the Valley of Five Lakes, south of Połczyn
Zdrój, at an altitude of $150 \mathrm{~m}$. The Drawa flows into the Noteć River below Krzyż, at an altitude of $28 \mathrm{~m}$, so the mean slope is 0.61\%o (Pawlaczyk, Łukaszewski 1992). The river is $199 \mathrm{~km}$ long, and the catchment covers an area of $3296.4 \mathrm{~km}^{2}$. The section of the river included in the Drawieński National Park is $45 \mathrm{~km}$ long, and the difference in altitude between the beginning and end of the section is 39 $\mathrm{m}$. Thus the mean slope is $0.87 \mathrm{~m} / \mathrm{km}$, i.e. about $1.0 \%$ (Pawlaczyk 1992). Because of this, the river in the area of the Park is similar to submontane rivers, especially in the water-gap section of about $15 \mathrm{~km}$ in length.

During its flow across the Park, the Drawa receives water from two major left-bank tributaries, Korytnica and Płociczna, from several minor right-bank tributaries, and from many streams. Thanks to this, water flow intensity is nearly doubled at the point where the river flows out of the Park (Stare Osieczno), especially during periods of drought. When the water level is high, the increase in water flow intensity is smaller, as shown in Table 1.

The aim of this paper is to give new information on habitat and growth conditions of $P . \times$ sparganifolius and $P . \times$ nericius. 


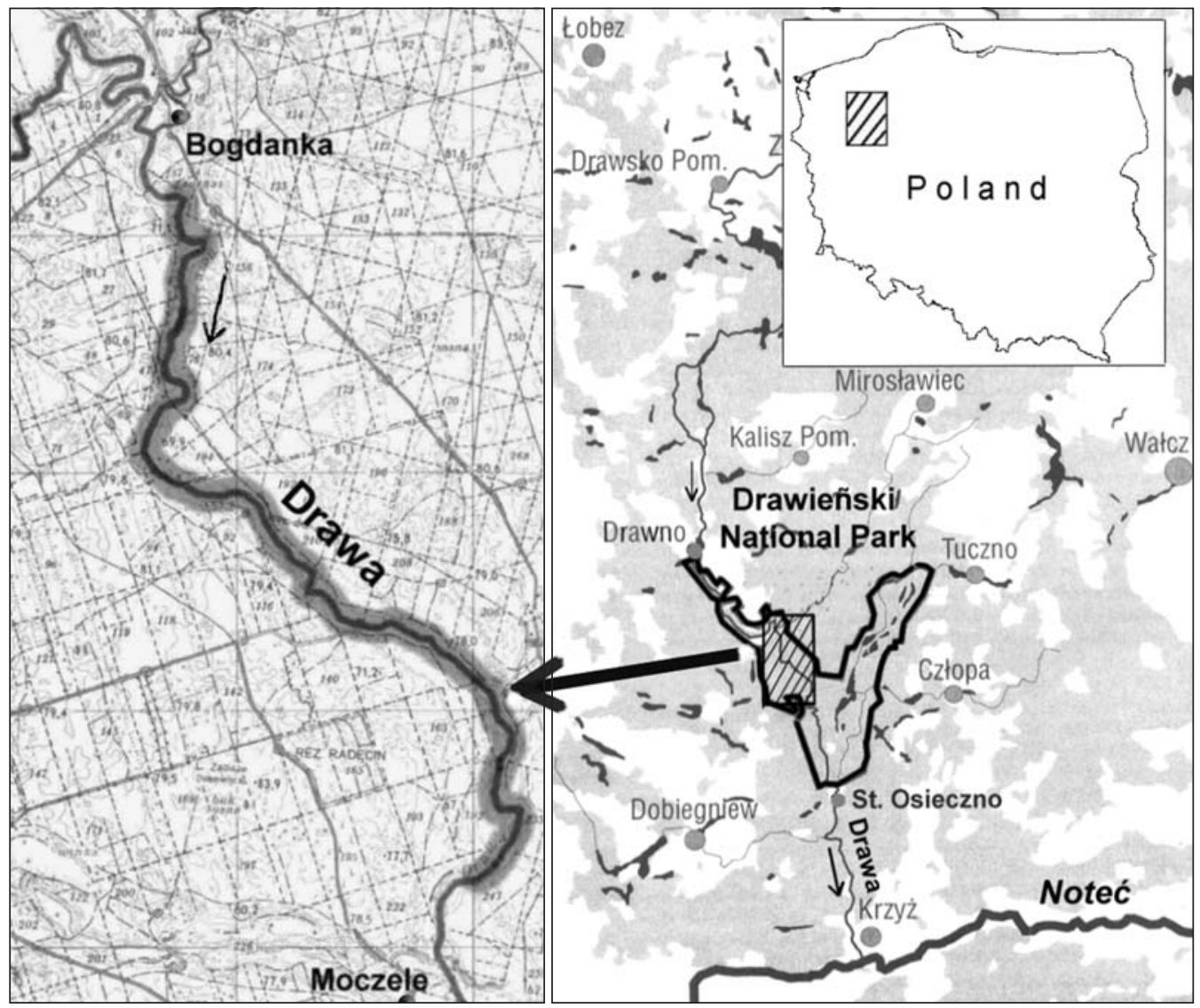

Fig. 1. Map showing the location of patches of Potamogeton $\times$ sparganiifolius in the Drawa River.
TABLE 1. Water flow intensity $\left(\mathrm{Q} \mathrm{m}^{3} \mathrm{~s}^{-1}\right)$ in the Drawa at points where the river flows into (Drawno) and out (St. Osieczno) of the Drawieński National Park (Nowacki et al. 1998).

\begin{tabular}{lccc}
\hline Measurement station & low & Water level \\
& middle & high \\
\hline Drawno & 5.52 & 8.68 & 12.5 \\
St. Osieczno & 10.6 & 13.4 & 18.2 \\
\hline
\end{tabular}

\section{MATERIAL AND METHODS}

Field research, aiming at detailed identification of the vegetation of the rivers Drawa and Płociczna within the borders of the Drawieński National Park, was started in 1997 and continued in 1998 and 1999 in periods of full development of aquatic plants. Analyses were conducted using classic phytosociological methods of Braun-Blanquet, describing and determining the density of each species in patches assigned to a given plant community. All investigations were carried out from a pontoon in the river current flowing through patches of vegetation. Thanks to this, we noticed the small elliptic floating leaves of $P . \times$ sparganifolius, clearly distinct from leaves of the Potamogeton pectinatus.

To make a detailed analysis of the floristic composition of patches of aquatic communities, plant specimens were collected in many parts of the phytocoenoses by means of a special anchor. Specimens that were difficult to identify were analysed in the laboratory and preserved in the herbarium. In the case of $P . \times$ sparganifolius (Fig. 2), a large number of specimens was collected to enable a precise identification and verification by specialists.

The places where phytosociological relevés were recorded, were marked on a map of scale of 1:10 000. In patches with $P . \times$ sparganifolius, 25 relevés were prepared, and 18 of them were tabulated to present the floristic composition of patches with this species.

$P . \times$ nericius (Fig. 3) was represented by a very small number of individuals. Specimens of this taxon were scattered along edges of two patches with $P . \times$ sparganifolius and did not form separate aggregations.

The collected hybrids were identified by means of the "New Flora of the British Isles" (Stace 1997). To confirm the results, the collection of specimens were sent to Dr J. Zalewska-Gałosz of the Department of Plant Taxonomy and Phytogeography, Jagiellonian University, Kraków. She finally verified the material as $P . \times$ sparganifolius and $P . \times$ nericius.

Physicochemical properties of water in the Drawa River within the DNP were analysed in summer 1997 (Piotrowicz et al. 1998). Water $\mathrm{pH}$, concentration of soluble oxygen, saturation of water with oxygen, water temperature and specific conductivity were measured in the field with the use of the multiparameter sonde 600R and data logger made by YSI Inc. Concentrations of nitrogen, phosphorus and some other elements were measured according to the Standard Methods for Water Examination (1992). Water colour, and concentration of chlorophyll $a$ were analysed according to Polish Standards.

\section{PLACE OF OCCURRENCE, HABITAT AND GROWTH CONDITIONS}

Potamogeton $\times$ sparganiifolius formed large patches in the Drawa within the Drawieński NP, which started 400$-600 \mathrm{~m}$ below the mouth of its left-bank tributary, the Korytnica River, and ended at a distance of about $5.5 \mathrm{~km}$ do- 


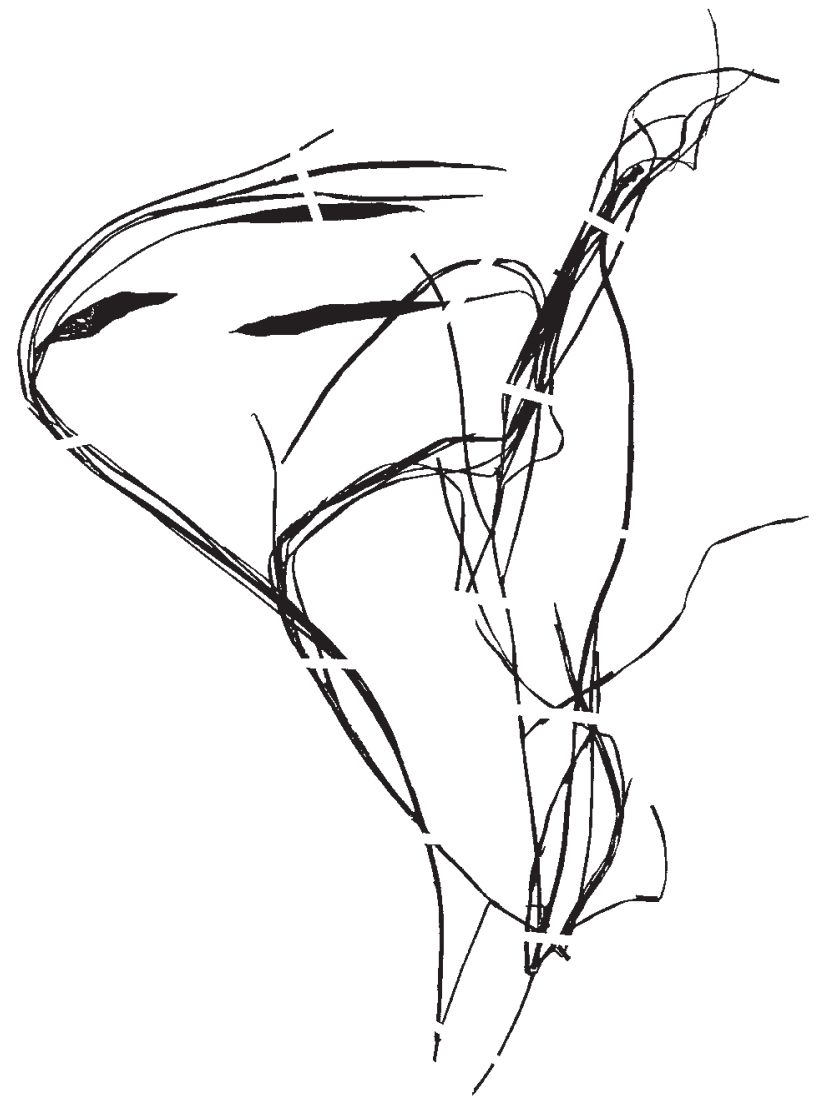

Fig. 2. General appearance of Potamogeton $\times$ sparganiifolius Least. ex Fr. (P. gramineus L. $\times P$. natans L. $)$, bar $=5 \mathrm{~cm}$.

wnstream, close to a bridge called "Na Moczele" (Fig. 1), while $P . \times$ nericius was found only at one side. In this section of the Drawa, the riverbed has a varied morphology. The valley is usually about $100-200 \mathrm{~m}$ wide, but in some places its width reaches $400-500 \mathrm{~m}$. Within the section of the Drawa colonized by $P . \times$ sparganiifolius, the morphology of the riverbed is characterized by numerous meanders. The valley of the winding river is limited on alternating sides by high, river-cut cliffs (bluffs), while the opposite bank is gentle (slip-off slopes), with point bars and swales. As a result, the relief of the riverbed is varied, with very shallow and very deep places. The sandy substrate of the Drawa is also modified by fallen logs. The variable rate of water flow resulting from the presence of vegetation in the river bed, results in formation of sandy bars parallel to the direction of flow (Pawlaczyk 1995). Such sandy shallows were usually colonized by $P . \times$ sparganiifolius. Patches of this pondweed were also found on bars composed of sand and gravel or - very rarely - of gravel and stones. Because of modification of the unstable and plastic sandy riverbed by the current and vegetation, the depth of water in its patches varied considerably. It ranged from over 100 $\mathrm{m}$ at the edges to about $20-50 \mathrm{~cm}$ in the central part of the patch. On gravel substrates, $P . \times$ sparganiifolius grew at a more uniform depth, of about $100 \mathrm{~m}$, although single patches occurred even at the depth of $150-160 \mathrm{~cm}$.

The rate of water flow among vegetation depended mainly on the size of individual patches. The presence of clumps of other plant species in the vicinity of $P . \times$ sparganiifolius resulted in creation of deep groves between the

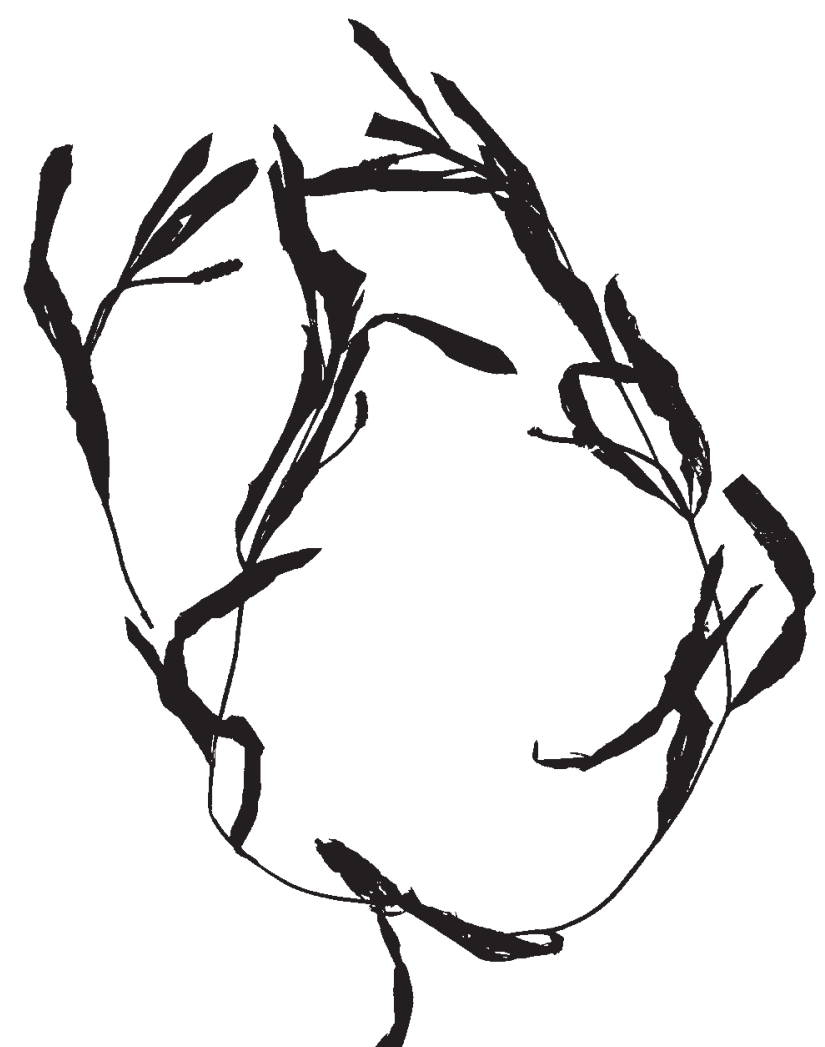

Fig. 3. General appearance of Potamogeton $\times$ nericius Hagstr. (P. alpinus Balbis $\times P$. gramineus L.), bar $=5 \mathrm{~cm}$.

patches, where the rate of water flow exceeded $1 \mathrm{~m} / \mathrm{s}$, whereas in the central part of the patch it was only $0.2-0.5 \mathrm{~m} / \mathrm{s}$. It must be noted that the rate of water flow at the edges of such patches in the Drawa was much higher than preferences of this taxon in British rivers (Dawson 1988). In patches colonizing harder substrates, such as gravel, the rate of flow varied from 0.5 to $0.8 \mathrm{~m} / \mathrm{s}$.

The size of some patches of $P . \times$ sparganiifolius reached several hundred $\mathrm{m}^{2}$ each. It was not always possible to assess their size precisely, especially when they were located in the main current and extended for several dozen metres.

$P . \times$ nericius was found only in one site, where it formed a small number of clumps along the edge of a patch with $P$. $\times$ sparganiifolius. Individuals of $P . \times$ nericius rooted in a small creek, on a substrate composed of mud and sand, at a depth of about $50 \mathrm{~cm}$. The rate of water flow was not noticeable, so it could be regarded as nearly stagnant.

The total concentration of mineral salts in water of Drawa within the DNP was relatively low - specific conductivity about $330 \mu \mathrm{S} \mathrm{cm}-1$. The water contained moderate amounts of $\mathrm{Ca}$ and $\mathrm{Mg}$, so the general alkalinity (about 2.6 mval $\mathrm{L}^{-1}$ ) and $\mathrm{pH}$ (about 7.4) were moderated. It is noteworthy that nitrates were absent in summer, while concentrations of nitrite $\left(0.002 \mathrm{mg} \mathrm{N} \mathrm{L}^{-1}\right)$ and ammonium (0.006 $\mathrm{mg} \mathrm{N} \mathrm{L}{ }^{-1}$ ) were low. Taking all into consideration means, that the intensive development of most species of aquatic plants was coming to an end, so there was no substantial demand for all nutrients, perhaps except for nitrates. Some properties of water quality changed only slightly between the northern and southern border of the Park (e.g. colour, 
$\mathrm{pH}$, hardness or concentration of chlorophyll $a$ ) and some properties did not change within the Park at all (e.g. saturation of oxygen or conductivity).

\section{FLORISTIC COMPOSITION OF PATCHES WITH P. $\times$ SPARGANIIFOLIUS}

In all analysed patches, $P . \times$ sparganiifolius was the dominant taxon (Table 2). Its degree of cover ranged from over $50 \%$ to nearly $100 \%$, particularly in the centre of the patch. The long, dense, undulating shoots were similar to those of $P$. pectinatus, but were distinguished by lanceolate floating leaves. The differences were visible only at a small distance - they could not be noticed by a person standing on the bank. The most common accompanying species were $P$. perfoliatus and $P$. pectinatus. The former species was a component of all patches with $P . \times$ sparganiifolius, while ( $P$. pectinatus) was present in most patches, but their degree of cover usually did not exceed $25 \%$. The high constancy of those accompanying species attests to their overlapping habitat preferences in respect of substrate and rate of water flow. Also Butomus umbellatus f. vallisneriifolia has similar preferences, but it usually colonizes deeper and more shaded sites.

Sporadic species found in the analysed patches include Sparganium emersum $\mathrm{f}$. fluitans and Sagittaria sagittifolia $\mathrm{f}$. vallisneriifolia. Patches dominated by these species are frequent in the current of the Drawa (Kraska 1998), both within the borders of the Drawieński National Park and in the upper sections of the river, above Lake Grażyna in Drawno.

In some patches dominated by $P . \times$ sparganiifolius, small numbers of Lemna minor and Spirodela polyrrhiza were found, mainly in the centre of the patch, where the tangle of pondweed shoots gave them some support and decreased the rate of water flow.

$P . \times$ sparganiifolius reproduce vegetatively and tend to form a relatively large plant mass. Stems are long and re- ach more than one meter length. The density of vegetation with $P . \times$ sparganiifolius is well show in Table 2 . The spread of this hybrid is most likely to occur by vegetative reproduction through turions, just like fruits that this hybrid might be reproducing sexually.

\section{DISCUSSION}

So far, $P . \times$ sparganiifolius has not been found in other sections of the river, i.e. from Drawno to the mouth of the Korytnica River and from the southern border of the Park to the mouth of the Drawa. A barrier limiting or even inhibiting the spread of the taxon to lower sections of the river is the dam reservoir and hydroelectric power station at Głusko. Retention of water and blockage of water flow, make it impossible or very difficult for seeds, turions and plant fragments to be carried downstream with river water. However, it cannot be excluded that $P . \times$ sparganiifolius is present in those sections of the river. The occurrence of the taxon over a distance of $5.5 \mathrm{~km}$ suggests that the population is stable and long-lived.

Hybridisation within the genus Potamogeton is also observed at present. This seems to be confirmed by a recent discovery of $P . \times$ fluitans as a new taxon in the Czech Republic, at the presence of both putative parental species: $P$. natans and $P$ lucens (Kaplan 2001a). However, this is a very rare incident, as so far the hybrid $-P . \times$ fluitans - has been recorded in 9 countries, whereas both parental species are widespread in Europe and a large part of Eurasia, including Japan (Kaplan 2001b).

In stable populations, in respect of the area covered and age, vegetative propagation is the most common, while seeds are safeguards in the case of unfavourable growth conditions threatening the survival of the population (Van Vijk 1989). Isoenzymatic analyses indicate that variation within and between populations of $P$. pusillus L. and $P$. berchtoldii Fieber confirms the dominance of propagation by tu-

TABLE 2. Floristic composition of phytocoenoses of $P . \times$ sparganiifolius including phytosociological criteria - date: 26-07-1999.

\begin{tabular}{|c|c|c|c|c|c|c|c|c|c|c|c|c|c|c|c|c|c|c|c|c|}
\hline Succesive no of the record & 1 & 2 & 3 & 4 & 5 & 6 & 7 & 8 & 9 & 10 & 11 & 12 & 13 & 14 & 15 & 16 & 17 & 18 & & \\
\hline Character of bottom $^{\mathrm{a}}$ & sa & sa & sa & st & g & g & g & sa & sa & sa & sa & g & g & sa & g & sa & m-sa & m-sa & $\frac{8}{0}$ & 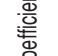 \\
\hline Depth $[\mathrm{cm}]$ & 120 & 100 & 100 & 100 & 120 & 160 & 150 & 140 & 140 & 140 & 120 & $0-70$ & $0-70$ & $40-70$ & 120 & $40-80$ & $40-80$ & $0-50$ & 范 & 吾 \\
\hline Surface of the record $(\mathrm{m} * \mathrm{~m})$ & $4^{*} 4$ & $8 * 5$ & $10 * 5$ & $10^{*} 10$ & $15^{*} 4$ & $4^{*} 10$ & $10^{*} 3$ & $10^{*} 6$ & $10^{*} 4$ & $20^{*} 4$ & $5^{*} 4$ & $10^{*} 4$ & $10 * 3$ & $20 * 5$ & $10^{*} 6$ & $10^{*} 10$ & $10^{*} 10$ & $20 * 5$ & & \\
\hline \multicolumn{21}{|l|}{ Genus Potamogeton } \\
\hline Potamogeton $\times$ sparganiifolius & 4 & 4 & 5 & 4 & 4 & 4 & 4 & 5 & 4 & 5 & 4 & 4 & 5 & 5 & 4 & 5 & 5 & 5 & $V^{4-5}$ & 7361 \\
\hline Potamogeton perfoliatus & 2 & 2 & 1 & 1 & 3 & 1 & 1 & 2 & 2 & 2 & 1 & 1 & . & 2 & 1 & + & + & 1 & $V^{+-5}$ & 1019 \\
\hline Potamogeton pectinatus & . & 1 & . & + & 1 & + & + & 1 & 2 & . & 2 & 1 & 1 & 1 & 1 & 1 & 1 & 2 & $V^{1-2}$ & 550 \\
\hline Potamogeton $\times$ nericius & . & . & . & . & . & . & . & . & . & . & . & . & . & . & . & . & + & + & $1^{+}$ & 3 \\
\hline \multicolumn{21}{|l|}{ Accompanying species } \\
\hline Butomus umbellatus f. submersa & . & . & + & + & 2 & + & 2 & . & + & 2 & . & . & . & . & + & + & . & . & $\left.||\right|^{+-2}$ & 308 \\
\hline Lemna minor & . & + & . & . & + & + & + & + & . & . & . & 1 & 1 & . & . & . & 1 & . & $\|\left.\right|^{+-1}$ & 97 \\
\hline Sparganium emersum f. submersa & . & . & . & . & . & . & . & . & . & . & . & . & 1 & . & . & . & . & + & $\mathrm{I}^{+-1}$ & 31 \\
\hline Veronica anagalloides & . & . & . & . & . & . & . & . & . & . & . & . & 1 & . & . & . & . & . & $I^{1}$ & 28 \\
\hline Elodea canadensis & . & . & . & . & . & . & . & . & . & . & . & . & 1 & . & . & . & . & . & $\mathrm{I}^{1}$ & 28 \\
\hline Spirodela polyrrhiza & . & . & . & . & . & . & . & . & . & . & . & . & + & . & . & . & . & . & $\mathrm{I}^{+}$ & 3 \\
\hline Sagittaria sagittifolia f. submersa & . & . & . & . & . & . & . & . & . & . & . & . & + & . & . & . & . & . & $1^{+}$ & 3 \\
\hline Myriophyllum spicatum & . & . & + & . & . & . & . & . & . & . & . & . & . & . & . & . & . & . & $\mathrm{I}^{+}$ & 3 \\
\hline
\end{tabular}

a character of bottom: $\mathrm{g}$ - graveled, sa - sandy, st - stony, $\mathrm{m}$ - muddy 
rions, even if the populations fruit abundantly (Kaplan \& Stepanek unpubl. data, after Kaplan 2001b). On the other hand, it is believed that in the presence of potential parents, crossing is easy, but the hybrid seed is often sterile or does not have any chances to develop among the densely packed individuals of the parental populations (Hollingsworth et al. 1996 after Kaplan 2001b). The spread of populations of the genus Potamogeton, including hybrids, takes place by means of seed produced as a result of intrapopulational self-fertilization or back-crosses (Fant et al. 2001, 2003).

In the case of the population of $P . \times$ sparganiifolius in the Drawa, one of the parental species ( $P$. gramineus) was absent, while the other ( $P$. natans) was infrequent and was never found in patches of the studied taxon (Table 2). However, $P$. natans was very common in the section of the Drawa above Lake Grażyna at Drawno. It was often accompanied by $P$. lucens, but $P . \times$ fluitans has never been recorded, although theoretically it could appear there as a result of crossing between the two species. It is believed to be the lack of one parent and the apparent reduction in range of the second suggests that the hybrid may be a more successful competitor at this site than one or both parents under current environmental conditions (Fant et al. 2003).

Both putative parents of $P$. nericius $(P$. alpinus and $P$. gramineus) were not observed there, either. Nevertheless, it is possible that thorough investigations may still reveal their presence in the study area.

\section{ACKNOWLEDGEMENTS}

We wish to thank Dr J. Zalewska-Gałosz for identification of herbarium specimens of both the Potamogeton taxa.

\section{LITERATURE CITED}

CLIVE S. 1997. New Flora of The British Isles, (Second Editiuon), Cambridge Univ. Press: pp. 1130.

DAWSON F.H. 1988. Water flow and the vegetation of running waters. In: J.J. Symones (ed.), Vegetation of inland waters. Handbook of vegetation science 15/1: 283-309. Kluwer Academic Publishers, Dordrecht.

FANT J.B., PRESTON C.D., BARRETT J.A. 2001a. Isozyme evidence for the origin of Potamogeton $\times$ sudermanicus as a hybrid between $P$. acutifolius and $P$. berchtoldii. Aquatic Botany. 71: 199-208.

FANT J.B., PRESTON C.D., BARRETT J.A. 2001b. Isozyme evidence of the parental origin and possible fertility of the hybrid Potamogeton $\times$ fluitans Roth. Plant Systematics and Evolution. 229: 45-57. Springer-Verlag.
FANT J.B., KAMAU E.M., PRESTON C.D. 2003. Chloroplast evidence for the multiple origins of the hybrid Potamogeton $\times$ sudermanicus Hagstr., Aquatic Bot. 75: 351-356.

HAEUPLER H. MUER T. 2000. Bildatlas der Farn- und Blütenpflanzen Deutschlands, Verlg E. Ulmer: 760. Stuttgart.

KAPLAN Z. 2001. Potamogeton $\times$ fluitans $(P$. natans $\times P$. lucens) in the Czech Republic. I. Morphology and anatomy. Preslia 73: 333-340. Praha.

KAPLAN Z., PLACKOVA I., STEPANEK J. 2001. Potamogeton $\times$ fluitans $(P$. natans $\times P$. lucens $)$ in the Czech Republic. II. Isozyme analysis. Preslia 74: 187-195. Praha.

KRASKA M. 1998. Roślinność rzek Drawy i Płcicznej w Drawieńskim Parku Narodowego (Vegetation of the Drawa and the Płociczna rivers of the Drawieński National Park). Department of Water Protection, Institute of Environmental Biology, University of Poznań: pp. 65, mscr. (in Polish)

NOWACKI F. 1999. Plan Ochrony Drawieńskiego Parku Narodowego - Operat ochrony Ekosystemów Wodnych (część abiotyczna), Protection Plan of the Drawieński National Park Statement of the Water Ecosystems Protection (abiotic part), mnscr.

PAWLACZYK P. 1992. Drawieński Park Narodowy (The Drawienski National Park) Lubuski Klub Przyrod., Swiebodzin: pp. 40.

PAWLACZYK P., ŁUKASZEWSKI D. 1992. Drawą przez Drawieński Park Narodowy (The Drawa River through the Drawienski National Park), Krajowy Przewod. Przyrod., Wyd. PTTK "KRAJ" Warszawa: pp. 66. (in Polish)

PAWLACZYK P. 1995. Ochrona procesów generowanych przez rzeki jako podstawa ochrony przyrody w ich dolinach. (The protection of river generated processes as a basis for nature protection in their valleys). Przegląd przyrodniczy 6(3/4): 235$-256$.

PIOTROWICZ R., KLIMASZYK P., KRASKA M. 1998. Wyniki badań fizyczno-chemicznych cech wód jezior i rzek Drawieńskiego Parku Narodowego. (Physico-chemical properties of lake and river waters in Drawieński National Park), Department of Water Protection, Institute of Environmental Biology, University of Poznań, pp. 118, mscr. (in Polish)

PRESTON C.D. 1989. Typification of Potamogeton sparganifolius Least.ex Fr. and P. natans subsp. kirkii Hooker Fil., Watsonia 17 (3): 361-363.

VAN VIJK R.J. 1989. Ecological studies on Potamogeton pectinatus L. III. Reproductive strategic and germination ecology. Aquat. Bot. 33: 271-299.

ZALEWSKA-GAŁOSZ J. 2001. Rodzaj Potamogeton L. w Polsce - taksonomia i rozmieszczenie (Potamogeton L. genus in Poland - taxonomy and distribution). Doctor thesis of Department of Plant Taxonomy and Phytogeography, Institute of Botany of Jagiellonian University: pp. 247. mscr. Kraków. (in Polish)

ZALEWSKA-GAŁOSZ J. 2002. Occurence and distribution of Potamogeton hybrids (Potamogetonaceae) in Poland. Feddes Repert. 113, 5-6: 380-393. 